\title{
A CLASS ACTION IN VARIOUS LEGAL SYSTEMS
}

\author{
Vladimir S. Sinenko, Yuliya V. Boltenkova, Anastasiya V. Tyurina, \\ Oksana S. Lilikova
}

85 Pobedy Street, Belgorod, the Belgorod region, 308015, Russia

\begin{abstract}
The article is devoted to the application of the class action institution in different countries and legal systems. The article deals with questions about the meaning of the institute of class action, interests protected with the help of it, positive and negative aspects of this institution are estimated. In addition, the article analyses characteristics and conditions of presentation of the class action. The research was conducted by using general scientific and specific methods of research including the analogy method, formal logical and comparative law methods. As a result, the Russian institute of class action, by its characteristics, is classified as a continental model. The analysis of the latest changes in Russian legislation reveals, at the same time, a tendency to converge with the Anglo-Saxon model of private class action.
\end{abstract}

Keywords: class action, civil procedure, joining a class, defense of collective rights, public interest, group litigation.

\section{INTRODUCTION}

The traditional civil process involves resolving the claim of a certain plaintiff to a certain defendant. In this case judgment affects the rights of only these parties. However, sometimes there is a need to protect collective interests. A class action is a procedural mechanism for the simultaneous protection of a large number of subjects. These subjects have the same or uniform interest. In Russia, the institution of class action developed within in the recent decade. Nowadays, the legislation on the protection of collective interests is rapidly developing and improving. It can be noted, that class action guarantees protection of rights and legitimate interests of large groups of people. This institution has already proved itself in advanced foreign legal systems.

Class actions are quite widespread in the legal systems of different states. In case of a class action a large group of people collectively bring a claim to court. This form of lawsuit is also called a representative action. In the review and scientific literature, we can find an analysis of this procedural institution in different legal systems, for example, in continental Europe countries [1] and common law countries [2].This form of collective lawsuit is very popular in the United States of America [3]. In addition, the institution is used in Latin American countries (for example, Brazil [4]), in Australia [5], South Africa [6], India [7] and others. In recent decade, the institute of class action appeared in Russian legislation. As a consequence, it became necessary to determine its main characteristics and make a comparative analysis.

\section{METHODS}

Various general scientific methods and the methods of logical cognition are used in the work: analysis and synthesis, systemic, functional and formal-logical approaches. The development of conclusions was facilitated by the application of formal-legal and comparative-legal methods.

\section{DISCUSSION AND RESULTS}

Historically, civil litigation has two parties: a plaintiff and a defendant. A plaintiff brings a claim against a defendant and the parties defend their rights in court independently or through a representative. However, sometimes it is necessary to protect a large number of subjects or an undefined group of persons. A class action (or representative action) is designed to protect the interests of many individuals in cases where their rights are violated by one act of the defendant. Such claims are possible when the losses of each of the claimants are too small for an individual claim.

In a class action lawsuit, the group of plaintiffs is represented by one or more lead plaintiffs. The injuries 
suffered and the allegations alleged by the lead plaintiff must be similar to those of the other class members. Otherwise, it will not be qualified as a class action.

Before starting a class action legal proceeding, the class must be certified by a judge. The lead plaintiff must demonstrate that the plaintiffs have a valid claim against the defendant and that all class members have similar claims. The lead plaintiff must also show that he or she can adequately represent all group members.

Once the class has been certified, the plaintiffs are notified of the lawsuit by mail or other means. All are automatically included in the lawsuit unless they opt out. Those that wish to opt out must follow a specified procedure. If they fail, they will remain part of the class.

Class actions are categorized as opt-in or opt-out, according to the rules of group members involvement in class actions. In opt-in actions, group members only acquire the right to bring a class action if it is a directly expressed their will (European law model). In opt-out class actions, all potential members of the group are assumed to be within it, if they do not declare their unwillingness to be members of the group (Anglo Saxonlaw model). That is, opt-out is a right that can be exercised either before or after certification of the group.

As is well known, the class action institute originated in England, but it has been most developed in the United States of America [8]. Unlike modern courts, the medieval English courts did not question the right of plaintiffs to sue on behalf of a group or a few representatives to defend an entire group. But group litigation was essentially dead in England after 1850.

The modern form of class actions in the United States appeared in 1938 with the adoption of Rule 23 of the Federal Rules of Civil Procedure (FRCP) [9] and was further developed by the 1966 amendments. Class actions are only allowed in civil cases and in the United States may be brought in federal or state court.

In accordance with Rule 23 of the Federal Rules of Civil Procedure one or more members of a class may sue or be sued as representative parties on behalf of all members only if:

(1) the class is so numerous that joinder of all members is impracticable;

(2) there are questions of law or fact common to the class;

(3) the claims or defenses of the representative parties are typical of the claims or defenses of the class; and

(4) the representative parties will fairly and adequately protect the interests of the class.

The Class Action Fairness Act was passed by Congress in 2005 to protect defendants from unfair lawsuits. It enables defendants to move their case from state court to federal court if the damages sought by plaintiffs exceed $\$ 5$ million. The class must consist of at least 100 plaintiffs. A third requirement has to do with diversity. Generally, diversity exists when the plaintiff and defendant reside in different states. For a class action lawsuit to be moved to federal court, one or more plaintiffs and defendant must reside in different states (or countries).

Class action in the US is based on an opt-out mechanism which means that all who belong to the «class» are bound by the judgement or the settlement unless they within a certain time limit opt-out of the action.

The most common reasons for using a class action in the USA are the following: pollution of the environment; mass production of low-quality products; mass production and sale of drugs harmful for human health; mass harm-doing caused by producers or sellers of goods, as well as by organizations carrying out work or rendering services.

The countries of the Romano-German legal system recognize the necessity of the institution of a class action and implement it. The EU countries use the term «collective redress mechanism» [10].

On June 11, 2013, the European Commission published Recommendation 2013/396 / EC on the general 
principles of the judicial and compensation mechanisms for collective compensation in the Member States regarding violations of the rights granted by Union legislation. [11] The EU member states were given two years from the publication of the Recommendation to implement in their regulation the main principles of collective harm compensation set out in the Recommendation in the following areas: protection of consumers' rights, investors, environment, personal data, antimonopoly regulation, financial services regulation.

In Germany, the class action was introduced in order to protect the rights of investors under the Model Law of Germany. In Germany there is a special form of group litigation - model case proceedings. Mechanisms of collective redress in Germany are in force (and were previously introduced) in areas of consumer protection and competition protection, telecommunications regulation, etc. [12].

In February 2014, France adopted a new Consumer Rights Protection Act, which allows filing of class actions in defense of consumer rights by associations approved by state bodies (came in force in March 2014). In March 2014, Belgium also included rules on class actions to protect consumer rights in the Economic Code (came in force in September 2014) [13]. Consumer protection organizations are entitled to file an action about defense of consumers in Belgium, Luxembourg, the Netherlands, Spain and Portugal [14].

The foregoing leads us to the conclusion that at present European countries are carrying out active work to introduce and finalize rules on class actions. This is done in order to protect the interests of certain broad groups of individuals.

In Russia, the institution of class action appeared in 2009 due to a new chapter in the Commercial Procedure Code of the Russian Federation (Chapter 28.2. Consideration of Cases on the Protection of Rights and Legitimate Interests of a Group of Persons).

In accordance with article 225.10 of the Commercial Procedure Code of the Russian Federation a legal entity or a natural person, participating in a legal relation, from which a dispute or claim arises, may apply to the commercial court for the protection of violated or disputed rights and legitimate interests of other persons, participating in the same legal relation. Bodies, organisations and individuals may likewise apply for the protection of rights and legitimate interests of a group of persons, where it is provided by federal law.

However, these supplements in legislation did not have much practical value. In the future, the class action institute was fixed in Art. 42 of the Code of Administrative Proceedings of the Russian Federation. The basis for a class administrative action is the existence of the following conditions:

(1) the large number of persons or the uncertainty of the number of its members, which make it difficult to resolve the claims of potential members of the group individually;

(2) the homogeneity of the subject matter of the dispute and the grounds for presentation of the relevant requirements by the group members;

(3) the presence of a common administrative respondent (administrative co-defendants);

(4) the use of the same way of protecting their rights by all group members.

Currently, a class action in Russia is rarely used. The most common cases of collective claims are the following: claims of depositors of large banks when they are bankrupt; claims of participants in the contract of shared housing construction; claims of tenants to the management company; claims of buyers to sellers of goods and services; claims for corporate disputes; claims for damages caused to an environmental offense; claims to tour operators.

One of the most important cases in Russian practice, which included three class actions at once, was a case against the tour operator «Labyrinth». As a result of claims consideration, the court decided to recover from 
the defendant about 37 million rubles in compensation.

The use of class actions to protect collective interests has both advantages and disadvantages. The advantages of a class action are: provide restitution to plaintiffs who would otherwise receive nothing because they cannot afford an attorney; help reduce the number of suits clogging the courts since one suit is filed instead of many small suits; reduce the cost of litigation (one suit is cheaper to litigate than many small ones); ensure that defendants with similar injuries are treated consistently (one decision applies to the entire class); motivate defendants to settle since there are many plaintiffs.

While they have some strong points, class actions lawsuits have disadvantages. Here are some of them: plaintiffs receive a very small award while attorneys earn large fees; cases take a long time to settle because of the complex procedures involved; class members give up their right to sue individually (they also cede control over the suit to the lead plaintiff and his or her attorney); the quality of legal representation affects all class members (if the lawyer does a poor job, all members suffer).

\section{CONCLUSION}

A class action is a type of lawsuit where one of the parties is a group of people who are represented collectively by a member of that group. Class action as a procedural institution spread around the world. Practically all major legal systems and states with developed legislation have class action in it. It is possible to single out models of a private class action (presented in the US legislation) and a class action to protect public interests (presented in the states of continental Europe).

The Russian class action institution is characterized by a continental model. This is due to the organic influence of the Romano-Germanic legal system on Russian law in general. Nevertheless, the recent reforms of legislation allow us to speak about a noticeable convergence of the Russian class action institution with the Anglo-Saxon model of private class action.

Granting the public institutions and private individuals the right to file a class action would be an effective means of protecting the rights of (1) consumers; (2) those who have suffered from environmental infringements; (3) participants of financial markets; (4) participants of corporate relationships, etc.

\section{CONFLICT OF INTEREST}

The authors confirm that the information provided in the article does not contain a conflict of interest.

\section{REFERENCES}

Commission Recommendation of 11 June 2013 on common principles for injunctive and compensatory collective redress mechanisms in the Member States concerning violations of rights granted under Union Law (2013/396/EU) // OJ. 2013. L 201. P. $60-65$.

Conradie P., Hofmeyr C. Class/collective actions in South Africa: overview /I https://uk.practicallaw.thomsonreuters.com/5-622-1521?transitionType=Default

\&contextData $=($ sc.Default $) \&$ firstPage $=$ true $\& b h c p=1$ (accessed 05 March 2018).

D'Angelo Chr.S., Canfield J.E. France and Belgium adopt class actions spring 2014 // http://www.lexology.com/library/detail.aspx?g=8443e157-67f8-4970-947d-131379fe12bf (accessed 05 March 2018).

Federal Rules of Civil Procedure // https://www.law.cornell.edu/rules/frcp (accessed 05 March 2018).

Gidi A. Class Actions in Brazil - A Model for Civil Law Countries // American Journal of Comparative Law. 2003. Vol. 51. P. 311, 315.

Haar B. Investor Protection through Model Case Procedures - Implementing Collective Goals and Individual Rights under the 2012 Amendment of the German Capital Markets Model Case Act (Kap-MuG) (Arbeitspapier Nr. 9/2013). P. 11 // http://papers.ssrn.com/abstract_id=2352248 (accessed 05 March 2018).

Hodges C. 2007. Europeanisation of Civil Justice: Trends and Issues. Civil Justice Quarterly. Vol. 26. January. P. 115.

Mulheron R. 2004. The Class Action in Common Law Legal Systems: A Comparative Perspective. Oxford; 
Portland, Or. : Hart, 535 .

Oberoi J., Mangaldas S. Class/collective actions in India: overview // https://content.next.westlaw.com/Document/I9dd07e50410011e598dc8b09b4f043e0/View/FullText.html?con textData $=($ sc.Default $) \&$ transitionType $=$ Default \&firstPage $=$ true \&bhcp $=1$ (accessed 05 March 2018).

Overview of existing collective redress schemes in EU Member States // http://www.europarl.europa.eu/document/activities/cont/201107/20110715ATT24242/20110715ATT24242E N.pdf (accessed 05 March 2018).

Overview of the Class Action Regime in Australia // https://www.quinnemanuel.com/the-firm/newsevents/article-february-2014-overview-of-the-class-action-regime-in-australia/ (accessed 05 March 2018).

Pace M. Nicholas Class actions in the United States of America: an overview of the process and the empirical literature

http://globalclassactions.stanford.edu/sites/default/files/documents/USA_National_Report.pdf (accessed 05 March 2018).

Per Larsson Class Action in the European Union /I http://www.consumerinfo.org.ua/upload/Reprts/en/ClassActionInEU.pdf(accessed 05 March 2018).

Valdes F. Procedure, Policy and Power: Class Actions and Social Justice in Historical and Comparative Perspective // Georgia State University Law Review. 2007 - 2008. Vol. 24. Issue 3. P. 630. 